\title{
PEMBERDAYAAN MASYARAKAT PERAJIN TENUN LURIK ATBM MELALUI INOVASI PRODUK
}

\author{
Nany Noor Kurniyati ${ }^{1}$ (nanykurniyati@gmail.com, Universitas Widya Mataram) \\ Kristiana Sri Utami ${ }^{2}$ (Universitas Widya Mataram) \\ I Made Sukanadi ${ }^{3}$ (Jurusan Kriya, Fakultas Seni Rupa, Institut Seni Indonesia Yogyakarta)
}

\begin{abstract}
The study aims to make effective model of empowerment of SMEs that can improve competitiveness and support the creative economy, so as to increase enterpreneurs that are oriented to product innovation. The specific target of the research is to obtain design and prototype of lurik weaving modification with natural fiber. The research was conducted with quantitative and qualitative approach, with Participatory Action Research (PAR) method. The research phase begins with the identification of human resources and product potentials, identifies the constraints faced by SMEs, followed by guidance and innovation development through design and prototype of lurik weaving modification with natural fiber. Based on the potential of human resources and products by considering the constraints faced by craftsmen, as well as based on the potential of natural resources (natural fiber) owned by the surrounding area, the researchers succeeded in making the design as the basis for creating prototype of the Lurik Abstract I Design, Lurik Abstract II, Lurik Dashed Lines Design, Lurik Mendong Combination Printing Design, Bamboo Lurik Feed Design and Lurik Combination Design.
\end{abstract}

Keywords: empowerment of SMEs, creative economy, lurik

\section{ABSTRAK}

Penelitian ini bertujuan membuat model pemberdayaan UKM secara efektif yang dapat meningkatkan daya saing dan mendukung ekonomi kreatif, sehingga mampu meningkatkan pelaku usaha yang berorientasi pada inovasi produk. Target khusus penelitian adalah memperoleh desain dan prototype modifikasi serat alam pada tenun lurik. Penelitian dilakukan dengan pendekatan kuantitatif dan kualitatif, dengan metode Participatory Action Research (PAR). Tahapan penelitian dimulai dengan pengidentifikasian potensi Sumber Daya Manusia (SDM) dan produk, pengidentifikasian kendala yang dihadapi UKM, dilanjutkan pembinaan dan pengembangan inovasi melalui pembuatan desain dan prototype tenun lurik modifikasi serat alam. Dengan mendasarkan pada potensi SDM dan produk dengan mempertimbangkan kendala yang dihadapi perajin, serta mendasarkan pada potensi sumber daya alam (serat alam) yang dimiliki daerah sekitar, maka peneliti berhasil membuat desain sebagai dasar untuk membuat prototype, yaitu Desain Lurik Abstrak I, Desain Lurik Abstrak II, Desain Lurik Garis Putus-Putus, Desain Lurik Mendong Kombinasi Printing, Desain Lurik Pakan Bambu, dan Desain Tenun Lurik Kombinasi.

Kata Kunci: pemberdayaan UKM, ekonomi kreatif, lurik 


\section{PENDAHULUAN}

Perkembangan dunia ekonomi dan bisnis telah mengalami pergeseran paradigma, yaitu dari ekonomi berbasis sumber daya ke arah paradigma ekonomi berbasis pengetahuan atau kreativitas. Hal ini dapat dilihat pada berkembangnya kelompokkelompok usaha yang peduli terhadap peningkatan kapasitas aset yang memiliki peluang untuk berinovasi dan mampu bertahan mengusung peran ekonomi kreatif dalam menghadapi perubahan lingkungan bisnis yang semakin dinamis. Pengembangan ekonomi kreatif merupakan upaya menciptakan sumber daya manusia yang mampu bersaing dengan kualitas yang dapat diandalkan. Ekonomi kreatif terdiri atas penyediaan produk kreatif langsung kepada pelanggan dan pendukung penciptaan nilai kreatif pada sektor lain yang secara tidak langsung berhubungan dengan pelanggan. Produk kreatif mempunyai ciri-ciri: siklus hidup yang singkat, risiko tinggi, margin yang tinggi, keanekaragaman tinggi, persaingan tinggi, dan mudah ditiru.

Ekonomi kreatif di pedesaan difokuskan pada aktivitas ekonomi yang memberikan multiplier effect cukup besar terhadap ekonomi daerah ditinjau dari: potensi pasar, potensi ekonomi, potensi untuk sukses, dan dampak terhadap rakyat miskin. Sebagian besar yang dijadikan aktivitas ekonomi utama suatu daerah adalah industri yang memiliki bahan baku yang berasal dari daerah itu sendiri. Oleh karena itu, diperlukan upaya untuk meningkatkan ekonomi kreatif di pedesaan. Selanjutnya, keberhasilan pembangunan ekonomi lokal maupun ekonomi nasional tidak dapat dipisahkan peranan sektor usaha kecil menengah. Sektor ini memegang peranan penting yang sangat sentral dan strategis dalam pembangunan daerah maupun pembangunan nasional, baik dilihat dari segi keterbatasan modal, SDM maupun keterbatasan dalam meningkatkan pendapatan masyarakat kecil, serta rendahnya kemampuan penyerapan tenaga kerja. Peningkatan ekonomi kerakyatan melalui pemberdayaan Usaha Kecil Menengah (UKM) mampu mengatasi masalah kemiskinan, menyediakan barang dan jasa dengan harga murah, serta merupakan salah satu komponen utama pengembangan ekonomi lokal.

Pentingnya peranan UKM dalam mengembangkan perekonomian nasional ditunjukkan dengan ditetapkannya UndangUndang RI nomor 20 tahun 2008 tentang usaha kecil dan selanjutnya diikuti dengan Peraturan Pemerintah RI nomor 32 tahun 2008 tentang pembinaan dan pengembangan usaha kecil. Inti dari peraturan ini adalah adanya pengakuan dan upaya untuk memberdayakan UKM. Dalam peraturan pemerintah tersebut disebutkan bahwa usaha kecil merupakan bagian integral dari perekonomian nasional yang mempunyai kedudukan, potensi, dan peranan yang penting dan strategis dalam mewujudkan pembangunan ekonomi nasional yang kokoh, sehingga usaha kecil perlu diberdayakan agar dapat menjadi usaha yang tangguh dan mandiri serta dapat berkembang menjadi usaha menengah. Berdasarkan data statistik pada tahun 2011, jumlah UMKM secara nasional mencapai 55, 2 juta unit.

Setiap UMKM rata-rata menyerap 3-5 tenaga kerja, jika ada penambahan sekitar 3 juta unit, tenaga kerja yang terserap bertambah 15 juta orang. Pengangguran menurun dari $6,8 \%$ menjadi $5 \%$ dengan pertumbuhan UKM tersebut. Tahun 2014 UKM menyumbang 56\% dari total PDB di Indonesia (BPS, 2015). Hal ini mencerminkan peran serta UKM terhadap laju pertumbuhan ekonomi yang memiliki signifikansi cukup tinggi bagi pemerataan ekonomi Indonesia karena memang berperan banyak pada sektor 
riil. UKM lebih bermain di sektor riil yang memenuhi hajat hidup orang banyak, sehingga bermanfaat tidak hanya bagi pertumbuhan ekonomi, tetapi juga pemerataan kesejahteraan rakyat.

Program pemberdayaan UKM di tingkat daerah telah berjalan secara baik, namun bagi banyak kalangan dirasakan masih berjalan lamban, sehingga upaya percepatan pembangunan UKM dalam agenda percepatan reformasi ekonomi mengindikasikan perlunya upaya percepatan pembangunan UKM di Indonesia pada masa mendatang. Pemberdayaan sektor UKM berkaitan dengan banyak aktor dan banyak variabel.

Salah satu usaha kecil dan menengah yang mampu memberikan kontribusi signifikan terhadap pertumbuhan ekonomi lokal di Kabupaten Sleman adalah UKM Kerajinan Tenun Lurik ATBM. Akan tetapi sejak perkembangannya hingga saat ini, jenis dan motif maupun produk turunan tenun lurik masih sangat terbatas. Oleh karenanya, salah satu cara yang dapat ditempuh untuk meningkatkan daya saing produk UKM Kerajinan Tenun Lurik guna meningkatkan daya saing dan mendukung ekonomi kreatif di Kabupaten Sleman adalah memberdayakan pelaku UKM Kerajinan Tenun Lurik ATBM melalui model pemberdayaan UKM kerajinan tenun lurik berbasis inovasi produk pada kelompok-kelompok usaha sesuai dengan potensi ekonomi yang ada di sekitarnya serta tingkat kemampuan yang dimilikinya.

Dalam upaya itu diperlukan suatu model pengembangan yang tepat untuk pelaku UKM berdasarkan potensi ekonomi, serta potensi dasar yang dimiliki oleh pelaku UKM, baik kelompok maupun perorangan. Pemodelan pengembangan kelompok ini menjadi kunci jawaban keberhasilan usaha. Oleh karena itu, diperlukan kejelian dalam menyusun dan membentuknya.

\section{METODE PENELITIAN}

\section{Desain Penelitian}

Penelitian ini hendak menganalisis dan menawarkan suatu model pemberdayaan UKM melalui inovasi produk guna meningkatkan daya saing dan mendukung ekonomi kreatif, sehingga penelitian ini dikategorikan penelitian terapan dalam konteks penelitian dan pengembangan (research and development/R\&D). Metode penelitian ini adalah penelitian deskriptif dengan mengintegrasikan pendekatan kuantitatif dan kualitatif dengan tujuan agar temuan penelitian dapat menggambarkan suatu model pemberdayaan UKM untuk mendukung ekonomi kreatif, sehingga diharapkan dapat ditemukan model pemberdayaan UKM tenun lurik ATBM di Kabupaten Sleman, Daerah Istimewa Yogyakarta.

\section{Pendekatan Penelitian}

Berdasarkan permasalahan tersebut, metode yang akan digunakan adalah eksperimen dengan pendekatan kualitatif. Proses pengumpulan data terbagi menjadi dua, yakni pengumpulan data primer dan sekunder. Proses pengumpulan data memegang peranan penting karena data menjadi tulang punggung dalam setiap studi. Proses pengumpulan data primer, antara lain ditempuh dengan cara: (1) Survei, (2) Review, (3) Kuesioner, (4) Wawancara Mendalam (indepth interview) dan Diskusi Kelompok Terfokus (focus group discussion/FGD), (5) Eksperimen. Data sekunder dikumpulkan melalui penelusuran arsip dan dokumen terkait pada Disperindagkop Sleman ataupun data yang dimiliki kecamatan dan kelurahan.

\section{PEMBAHASAN}

Tenun Lurik

Kerajinan tenun lurik merupakan salah satu kerajinan tradisional yang merupakan 
aset budaya sebagai peninggalan nenek moyang bangsa Indonesia. Pada zaman dahulu kerajinan tenun lurik ini dikenal dalam masyarakat Jawa sebagai bahan untuk membuat baju surjan yang dipakai sebagai baju adat terutama oleh kerabat maupun para prajurit Keraton Ngayogyakarta Hadiningrat.

Lurik berasal dari kata korek, yang dalam bahasa Kuno lorek berarti lajur atau garis, dan dapat pula berarti corak (Zoetmulder, 1982: 575). Pada zaman dahulu, kain lurik ditenun dengan alat yang disebut gedog atau gedhong. Dalam perkembangannya untuk mencapai hasil produksi yang lebih cepat, para perajin tenun lurik beralih menggunakan Alat Tenun Bukan Mesin (ATBM) yang hingga saat ini masih dipertahankan sebagai alat pembuatan tenun lurik di berbagai daerah di Pulau Jawa (Isyanti, 2003: 18).

Tenun lurik merupakan salah satu wujud kekayaan budaya tradisional Jawa. Sebagai salah satu bentuk kain tradisional, tenun lurik bukan hanya berfungsi sebagai pakaian semata, namun juga memiliki nilai filosofi yang sangat penting bagi masyarakat sebagaimana diungkapkan oleh Risman Marah dalam buku Berbagai Pola Kain Tenun dan Kehidupan Perajinnya, bahwa masyarakat Jawa adalah masyarakat yang sangat kental dengan suasana hidup mistis yang dilatarbelakangi oleh kebudayaan Hindu yang melingkupinya di masa lampau. Penciptaan tenun lurik dilakukan bukan hanya untuk mengisi waktu luang yang setelah mereka panen dan menanami sawah-sawahnya kembali hingga menunggu masa panen berikutnya, tetapi lebih jauh lagi telah bersinggungan dengan kepentingan kepercayaan, perasaan sakral, dan pemuasan akan cita rasa keindahan.

\section{Perajin Tenun Lurik "Maju Mandiri”}

Perajin Tenun Lurik "Maju Mandiri" terdiri atas delapan perempuan ibu rumah tangga, dengan tingkat pendidikan rata-rata Sekolah Dasar (SD) sebanyak empat orang, tingkat pendidikan SMP sebanyak satu orang, tingkat pendidikan SMA sebanyak dua orang dan tidak sekolah sebanyak satu orang. Data usia perajin dengan rentang 30-44 tahun berjumlah 1 orang, usia 45-59 tahun berjumlah 2 orang, dan di atas 60 tahun sebanyak 5 orang. Perempuan perajin ini menjadikan tenun lurik sebagai bagian dari sumber mata pencaharian, di samping sebagai petani. Kedelapan perempuan ini memiliki harapan tinggi akan kehidupan di masa yang akan datang melalui usaha tenun lurik. Dalam proses produksi belum ada spesialisasi pekerjaan, sehingga setiap perajin dapat melakukan tahapan dalam proses produksi.

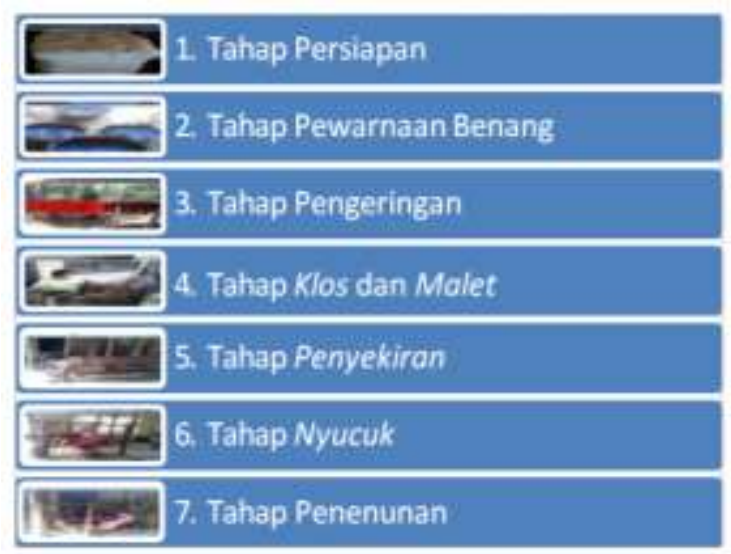

Gambar 1. Tahapan Proses Produksi

Proses produksi tenun lurik "Maju Mandiri" terdiri dari 7 (tujuh) tahapan, yaitu persiapan (alat, bahan baku benang, bahan penolong), pewarnaan benang, pengeringan, klos dan malet, penyekiran, nyucuk, dan penenunan. Perajin selama ini menenun lurik tanpa modifikasi. Variasi hasil tenun lebih pada permainan warna benang dan motif lorek, sehingga hasil tenunan relatif monoton. Benang yang digunakan berupa benang katun 
dan poliester. Kain lurik hasil produksi perajin ini biasanya dipesan oleh instransi-instansi swasta dan pemerintah serta masyarakat umum untuk membuat baju seragam. Jumlah permintaan masih terbatas, hal ini disebabkan peminat tenun lurik kalangan terbatas.

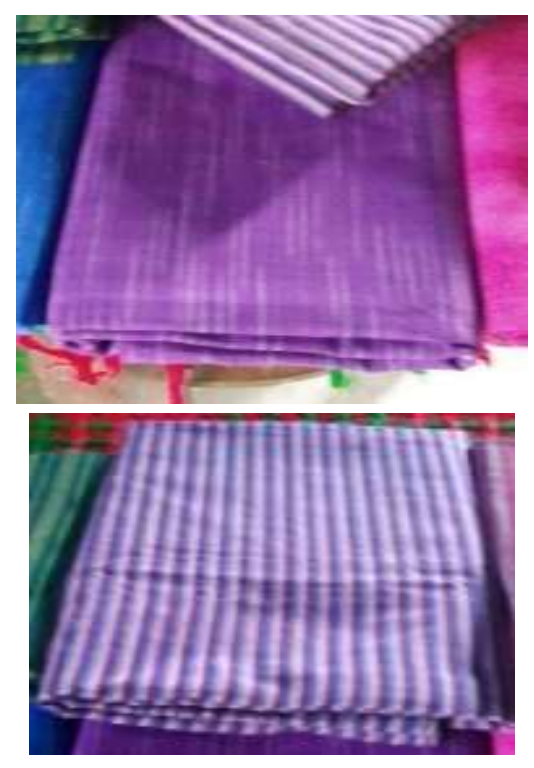

Gambar 2. Tenun Lurik sebelum Inovas

Inovasi produk pada tenun lurik ini dilakukan peneliti dengan memanfaatkan serat alam. Serat alam sebagai bahan modifikasi banyak tersedia di daerah sekitar, antara lain mendong, enceng gondok, lidi, bambu, dan limbah kepompong. Serat alam ini dapat digunakan setelah melalui proses pengeringan dan pewarnaan sesuai kebutuhan. Pemanfaatan sumber daya alam lokal ini dapat menjadi solusi, sehingga hasil tenun tidak terkesan monoton. Inovasi dilakukan dengan menjadikan serat alam sebagai pakan dalam proses penenunan. Dengan mempertimbangkan ketersediaan serat alam yang cukup banyak di daerah sekitar, peneliti membuat beberapa desain tenun lurik modifikasi serat alam dengan memanfaatkan mendong, enceng gondok, bambu, lidi, dan limbah kepompong.

Desain tenun lurik modifikasi serat alam dihasilkan peneliti dengan mempertimbangkan aspek inovasi, pemanfaatan hasil alam yang mudah diperoleh, dan aspek peluang pasar. Desain tersebut, yaitu Desain Lurik Abstrak I, Desain Lurik Abstrak II, Desain Lurik Garis PutusPutus, Desain Lurik Mendong Kombinasi Printing, Desain Lurik Pakan Bambu, dan Desain Tenun Lurik Kombinasi. Selanjutnya, desain-desain ini oleh perajin akan diwujudkan dalam bentuk prototipe tenun modifikasi. Berikut ini adalah desain-desain tersebut:

\section{Lurik Pakan Mendong Warna Ungu}

Tenunan ini dirancang dengan lajurlajur benang lungsi yang berwarna-warni serta ukuran masing-masing bidang relatif lebar. Hal ini dilakukan dengan pertimbangan untuk memberi ruang bila tenunan ini dieksplorasi dengan tambahan motif tertentu dengan teknik sulam, payet, tapis, maupun bordir. Hasil tenunan ini dimanfaatkan sebagai media dasar pembuatan produk-produk kreatif fungsional, seperti tas wanita. Menggunakan pakan mendong warna ungu merupakan salah satu alternatif warna yang memberi kesan lebih soft, sehingga memberi ruang yang lebih luas bila nanti dieksplorasi dengan motif-motif dan warna-warna yang lebih cerah. Di samping itu, pakan dengan menggunakan mendong menghasilkan kain tenunan yang lebih tebal serta memiliki karakter yang unik.

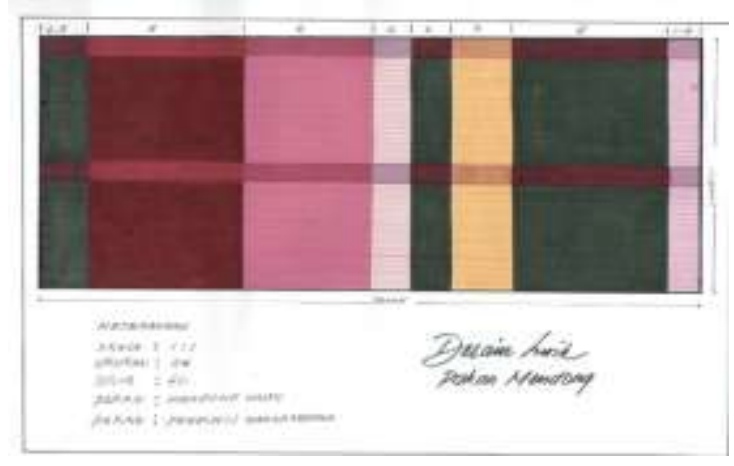

Gambar 3. Desain Lurik Pakan Mendong Ungu

\section{Lurik Pakan Mendong Hijau}

Kain tenunan ini masih menggunakan benang lungsi yang sama dengan lurik pakan 
mendong ungu, hanya pakan mendongnya diganti dengan menggunakan mendong berwarna hijau. Penggantian warna pakan memberi hasil tenunan yang lebih cerah terutama pada benang lungsi yang berwarna hijau, yang sebelumnya sudah dirancang dengan benang lungsi yang didominasi warna hijau. Penggunaan pakan dirancang berselang-seling, yaitu 20 kali menggunakan pakan mendong lalu dikunci dengan pakan benang sebanyak 20 kali gedogan atau bantingan. Proses ini dilakukan secara teratur, sehingga hasil tenunan terkesan unik dengan karakter yang sangat menarik bila dijadikan bahan dasar produk-produk kreatif lainnya.

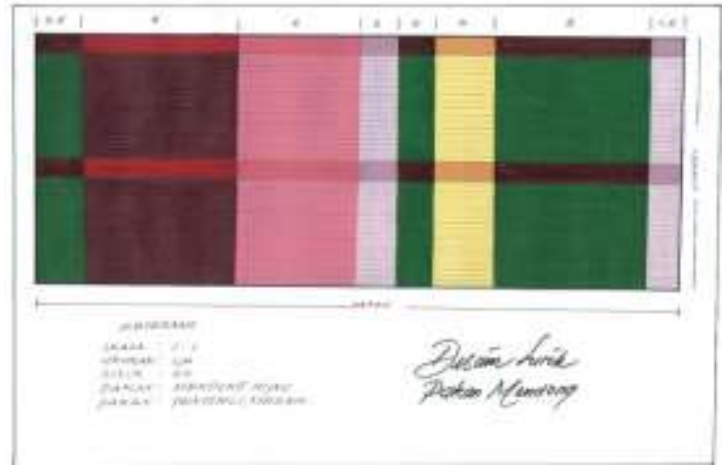

Gambar 4. Desain Lurik Pakan Mendong Hijau

\section{Lurik Pakan Mendong Orang}

Desain tenunan ini tidak jauh berbeda dengan kedua tenunan di atas, dari segi susunan dan warna benang lungsi maupun penggunaan jenis pakannya, hanya pakannya dengan mendong diberi pewarna orange. Pembeda dalam tenunan ini adalah penerapan pakan mendong berselang-seling cukup rapat, teratur secara terus-menerus, yaitu 4 kali penerapan pakan mendong lalu dikunci dengan pakan benang sebanyak 20 kali gedogan atau bantingan, sehingga hasil kain tenunannya berbeda dengan lurik sebelumnya, walaupun menggunakan benang lungsi dan benang pakan yang sama.

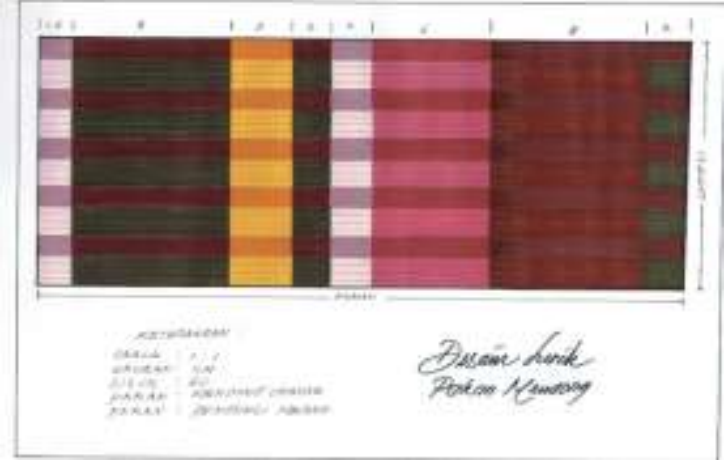

Gambar 5. Desain Lurik Pakan Mendong Orange

\section{Lurik Pakan Tampar Agel}

Kain tenunan ini dirancang menggunakan pakan tampar agel dengan benang lungsi berwarna-warni yang cukup cerah serta dengan ukuran bidang masingmasing warna relatif lebar, sehingga memberi kesan ruang yang cukup bila dieksplorasi lagi dengan kombinasi teknik dan motif lain. Teknik penerapan pakannya dengan teknik berselang-seling yang relatif rapat, teratur, secara terus-menerus, yaitu 4 kali pakan tampar agel lalu dikunci dengan pakan benang 20 kali gedogan atau bantingan. Hasil tenunannya berwarna soft dengan karakter tampar agel bertekstur sangat unik.

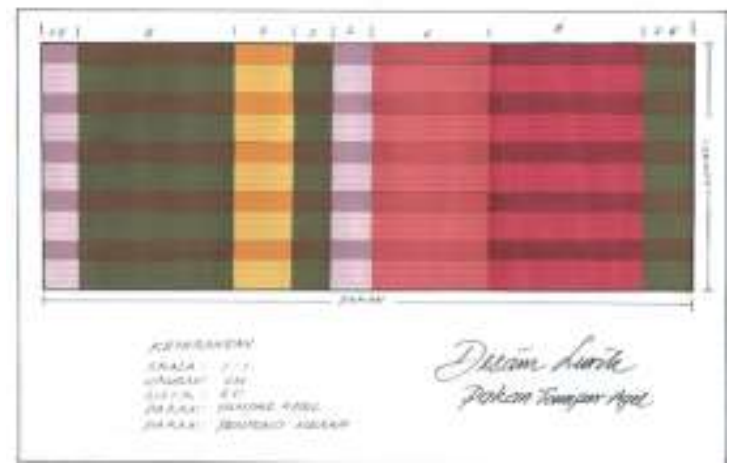

Gambar 6. Desain Lurik Pakan Tampar Agel

\section{PENUTUP}

Sumber daya alam lokal yang tersedia di daerah sekitar dapat bermanfaat bagi usaha kecil menengah (UKM) dalam peningkatan inovasi produk. Pemanfaatan ini dilakukan dengan menggunakan serat alam mendong, enceng gondok, lidi, agel, dan serat lainnya, yang dihasilkan daerah sekitar untuk 
menciptakan motif dan desain baru pada tenun lurik. Oleh karena itu, penelitian ini diharapkan dapat membantu UKM terutama perajin tenun lurik ATBM untuk mengembangkan produk yang inovatif dan kreatif. Hal ini tidak menutup kemungkinan dapat diterapkan oleh para perajin tenun lurik di daerah lain dengan memunculkan ciri-ciri khas masing-masing daerah.

Penelitian lanjutan perlu dilakukan untuk mengembangkan produk yang inovatif dan kreatif. Berdasarkan prototipe yang sudah dibuat, mulai dilakukan eksperimen. Pembuatan prototipe produk turunan diawali dengan desain produk. Prototipe dilakukan dengan mengubah kain tenun lurik hasil modifikasi menjadi produk inovasi baru berupa kap lampu, penyekat ruang, tas, dompet, taplak meja, sajadah. Pembuatan prototipe ini mengikursertakan perajin dan mahasiswa. Selanjutnya, produk tenun lurik modifikasi ini dapat dijadikan sebagai souvenir khas Kabupaten Sleman. Hal ini secara tidak langsung akan mendukung ekonomi kreatif serta industri pariwisata di Daerah Istimewa Yogyakarta.

\section{DAFTAR PUSTAKA}

Affandi, Achmad Nur. 2011. "Inovasi dan Daya Saing UMKM." Makalah Seminar "Membangun dan Meningkatkan Daya Saing Nasional di Era Keterbukaan Ekonomi."

Muhardi. 2007. Strategi Operasi: untuk Keunggulan Bersaing. Edisi Pertama. Yogyakarta: Graha Ilmu.

Pangestu, M.K. 2008. Pengembangan Industri Kreatif Menuju Visi Ekonomi Kreatif Indonesia 2025. Departemen Perindustrian RI.
Pranarka. A.M.W., dan Vidhyandika. 1996. Pemberdayaan: Konsep, Kebijakan dan Implementasi. Diedit oleh: Onny S.P. dan Pranarka. Jakarta: Center of Strategic and International Studies.

Suharto, Edi. 2009. Membangun Masyarakat: Memberdayakan Rakyat. Bandung: Refika Aditama.

Tambunan, Tulus T.H. 2002. Usaha Kecil dan Menengah di Indonesia: Beberapa Isu Penting. Jakarta: Salemba Empat.

Utami, K.S. dan N.N. Kurniyati. 2013. "Strategi Pengembangan Usaha Kecil Menengah (UKM) Kreatif Pedesaan di Kabupaten Sleman Studi Kasus Subsektor Industri Kerajinan Anyaman Mendong." Artikel Prosiding dan Seminar Nasional Masyarakat Madani UII, Desember 2013.

Utami, K.S dan Retnaningdiah D. 2014. "Upaya Pengembangan Ekonomi Kreatif melalui Usaha Kecil Tenun Lurik ATBM." Jurnal Kompetensi, Universitas Cokroaminoto Yogyakarta, ISSN:14129450,Vol.12,No.2, Juli-Desember 2014. 